the knowledge of this constant it is easy to deduce at once the value of a number of other important magnitudes with equal precision, e.g. the number of molecules in a cubic centimetre of any gas at standard pressure and temperature, and the mass of each of the atoms of matter. At the same time, the accurate evaluation of $e$ throws light on the magnitude of a number of related quantities.

While Prof. Millikan's work was in progress, Ehrenhaft examined the charge carried by particles so small that they showed a marked Brownian movement, and concluded that the charge in some of these cases was smaller than the value found by Prof. Millikan, or, in other words, that there existed a charge less than that carried by the negative electron or gaseous ion. This evidence is carefully examined by the author, who concludes that the discrepancies can be readily accounted for by experimental disturbances, and that there is no trustworthy evidence of the existence of a sub-electron.

Later chapters include a discussion of modern views of the structure of the atom and the nature of radiant energy. Very appreciative references are made to the value of Moseley's work, and its great importance in fixing the relation and modes of vibration of the elements is emphasised. The author is a supporter of the nucleus theory of the structure of the atom, and outlines clearly Bohr's contributions to the origin of spectra.

Prof. Millikan's book is written in a simple, almost popular, style. The argument throughout is well sustained, and the essential points are clearly brought out. Stress is laid on the underlying physical ideas, and the few calculations required are included in an appendix. We can recommend this volume most strongly both to scientific experts and to the general scientific public as an accurate and at the same time inspiriting account of an important field of scientific inquiry opened up in recent years.

E. R.

\section{A STUDY OF THE JEWISH CHILD.}

The Jewish Child: Its History, Folklore, Biology, and Sociology. By W. M. Feldman. With introduction by Sir James Crichton-Browne. Pp. xxvi +453 . (London: Baillière, Tindall, and Cox, 19I7.) Price ros. $6 d$. net.

$D^{R}$. FELDMAN'S study of the Jewish child should be of interest to English readers for at least two reasons. First, because out of a total of twelve million Jews in the world, one-fifth are, at present, living in English-speaking countries-more than two millions in America, and less than a quarter of a million $(240,000$, to be exact) in the United Kingdom. The second reason is that the British Government, with the consent of the Allies, proposes to use its best endeavours to establish, under the ægis of the British Government, a national home for the Jewish people in Palestine, where they might be at liberty to develop in accordance with their national aspirations.

Dr. Feldman is well qualified to lead us in the NO. 2525 , vOL. IOI] study of the Jewish child; for not only is he well acquainted with modern Jewish child-life, having a big practice among the Jews of Whitechapel, but he is also well versed in Jewish literature, ancient and medieval. His book represents the first attempt to give a comprehensive account of Jewish child-life in all its phases and aspects, and takes us through the whole life-cycle of the Jewish child, including the ante-natal, natal, and post-natal periods.

The book may be divided roughly into two parts, historical and scientific. The historical part deals with the state of knowledge of child-life among the ancient and medieval Jews. By means of numerous quotations and citations from the Bible, the Talmud, and Rabbinical literature, the author demonstrates, first that the Jews were keenly interested in all the phases of child-life, and secondly that the amount of true knowledge they possessed on this subject was not inconsiderable. For it must be noted that the broad principles of eugenics and hygiene were strictly enforced by the laws of Moses, and repeatedly enjoined by the teachings of the Rabbis as a religious duty. The scientific part, on the other hand, deals with such questions as the physical, biological, and pathological characteristics of the modern Jewish child.

One of the most important chapters in the book is that which discusses the vital statistics of the Jewish child. At a time when the problem of infant mortality looms large in the public eye, it is interesting to note that among Jews the infant mortality is, at all ages of child-life, considerably lower than among the general population, and not only in England, but in all other countries. The chances of surviving the critical first year are also much greater among Jewish infants. Contrary to the popular belief, the Jewish birth-rate is less, and yet their degree of increase is greater, than that of non-Jews. This is because their infant mortality is considerably lower. As Leroy-Beaulieu puts it, the Jews "bring fewer children into the world, but they bring more of them to maturity." "This low infantile mortality," Dr. Feldman reminds us, " is not due to any inherent racial vitality in the Jewish child, but is due to the almost universal prevalence of breast-feeding among Jewesses, to the lesser incidence or almost entire absence of transmissible taints resulting from diseases acquired by the parents in the worship of Venus and Bacchus, and lastly to the great general care bestowed on their children by Jewish parents, who fly to the doctor for almost every infantile ailment."

The chapter on the system of education among the Jews proves how highly education was valued by them so far back as 2000 years ago. This zeal for education, both Jewish and secular, is still very marked among the Jewish population of the East End. Among other subjects, the author discusses the effects of first-cousin marriages among the Jews. He also gives us an interesting and lucid account of the recent study of Jewish physiognomy by Dr. Redcliffe Salaman, who came to the conclusion that the Jewish type of face is a 
recessive Mendelian character, a conclusion which has a bearing on the question of intermarriage and the purity of the Jewish race.

One or two criticisms must be made on an otherwise excellent book. A number of misprints occur, and the author repeats himself occasionally in a way that must affect unpleasantly the attentive reader. Some of the quotations are naive and often irrelevant to the main purpose of the book. The whole chapter on the mathematical problems of the Talmud is outside the scope of the book. In general, one must say that the author gives too much, and one often wonders whether he is writing about the Jewish child or the Jewish family. Finally, is it to be taken as a compliment to our French Allies that the author gives most of the "indecent" quotations in French? This prudery is perhaps out of place in a scientific book. But these minor imperfections can, no doubt, easily be remedied, and we hope that this excellent compilation will be rendered more perfect in a second edition, which the book richly deserves.

\section{J. Brodetsky.}

\section{OUR BOOKSHELF.}

The Linacre Lecture on the Law of the Heart. Given at Cambridge, I9r5. By Prof. E. H. Starling. Pp. 27. (London : Longmans, Green, and Co., Igr8.) Price Is. 6d. net.

IN this lecture Prof. Starling has embodied the main results of the researches which he has carried out during the last few years on the work of the heart. The starting point of the investigation was the introduction by Knowlton and Starling of the heart-lung preparation by means of which the output and efficiency of the heart could be accurately studied under practically normal conditions. By this method the influence of changes in arterial and venous pressure on the output and volume of the heart, its oxygen supply, and its efficiency have been gradually worked out. The evidence obtained from this many-sided research has gradually led up to general conclusions of fundamental importance, one of which gives the lecture its title, and states that "the energy of contraction" of cardiac muscle "is a function of the length of the muscle fibre." In fact, the longer the fibres at the beginning of systole, the stronger is the force of the beat. This property of cardiac muscle, which is equally manifested by skeletal muscle, makes clear, for the first time, the real nature of the so-called "reserve power" of the heart. A rise of arterial pressure or an increase in venous inflow produces a greater diastolic volume of the heart-that is to say, an increased length of its fibres; the heart therefore contracts more forcibly, thereby maintaining its output against a high arterial pressure, or increasing its output when the venous inflow becomes larger.

This principle is not merely of physiological value, but also of far-reaching importance in pathology, and although the author only hints at this NO. 2525 , VOL. IOI] aspect, it must have an enormous influence on the clinical treatment of many diseases of the heart.

Plant Materials of Decorative Gardening: The Woody Plants. By Prof. W. Trelease. Pp. 204. (Urbana: Published by the Author, I9r7.) Prof. Trelease's object in this little hand- or pocket-book is an attempt to make it possible for a careful observer to learn the generic and usually the specific names of any hardy tree, shrub, or woody climber that may be found cultivated in the eastern United States-excluding the extreme south-or in northern Europe except in the more pretentious estates or botanical establishments. The manual, which is of a convenient size, has been very carefully and thoughtfully compiled. Some 247 genera and 782 species, with a number of minor forms, are dealt with-in all, I 50 distinct kinds of plants belonging to eightythree natural families. The book opens with dichotomous keys to the genera, which have been found to work very well, and are followed under each genus by keys to the species, a description of each genus being given before the keys. In addition to the Latin names, the common names of the plants are also given.

For the gardens of eastern North America no doubt the keys to the species are ample, but for Great Britain in many cases they are too meagre. Under Cotoneaster, for instance, of the six species mentioned only one, C. microphylla, is commonly found in our gardens, while many familiar species cultivated in this country are omitted. Berberis affords another example, as our gardens are getting filled with new introductions from China, of which no mention is made.

The principle of the manual is good, however, and in such features as it may be lacking we have other books to hand which fill its gaps. One of its chief merits is the vast amount of information it compresses into a small space.

There is a useful glossary at the end, and also a carefully prepared index.

Laboratory Glassware Economy. A Practical Manual on the Renovation of Broken Glass Apparatus. By Prof. H. B. Dunnicliff. Pp. $\mathrm{x}+$ 92. (London : Macmillan and Co., Ltd., I9I7.) Price $4 s$. net.

To overcome the great difficulty experienced by teachers of practical chemistry in Indian colleges in procuring supplies of glassware during the war, Prof. Dunnicliff devised a number of easy methods of renovating and adapting to new uses damaged apparatus made of glass. In this workmanlike little book he describes the processes he has developed and explains how difficulties may be surmounted with success. Teachers in charge of chemical laboratories at home will find the volume very useful, and the uses for damaged calcium chloride tubes, broken test-tubes, flasks, retorts, burettes, and so on, will show them how they may both effect economy and maintain efficiency. 